\title{
Valorization of non-timber forest products in Mayo- Rey (North Cameroon)
}

\author{
Obadia Tchingsabe ${ }^{* 1}, 3$, Arlende Flore Ngomeni1, Pierre Marie Mapongmetsem ${ }^{2}$, Nwegueh Alfred \\ Bekwake ${ }^{1}$, Ronald Noutcheu ${ }^{3}$, Siergfried Didier Dibong ${ }^{3}$, Mathurin Tchatat ${ }^{1}$ and Guidawa Fawa ${ }^{2}$ \\ 1. The Institute of Agricultural Research for Development (IRAD), Nkolbison, B.P. 2067 Yaoundé, Cameroon \\ 2. Laboratory of Biodiversity and Sustainable Development, University of Ngoundere, B.P. 454 Ngaoundere, \\ Cameroon \\ 3. Laboratory of Biology and Plant Physiology of Organisms of Douala, B.P. 2701 Douala, \\ Cameroon. \\ *1, 3 Corresponding author email: tchingsabe@yahoo.fr \\ Original submitted in on 19th October 2016. Published online at www.m.elewa.org on 31'st December 2016 \\ http://dx.doi.org/10.4314/jab.v108i1.2
}

\begin{abstract}
Objective: Studies were conducted to characterize the Non-Timber Forest Products (NTFPs) from the locality of MayoRey in the North Region of Cameroon for their subsequent domestication.

Methodology and Results: An ethnobotanical survey was conducted among 200 people drawn from four ethnic groups (Laka, Lamé, Peulh and Toupouri). This study has identified 107 plant species including 54 species food (vegetables, fruits and traditional drinks). The species Dioscorea bulbifera, Burnatia sp., Parkia biglobosa, Detarium microcarpum, Adansonia digitata, Vitellaria paradoxa, Ziziphus mauritiana, Ximenia americana and Vitex doniana were identified as major species of this town, due to their socio-economic importance. Plant parts used in the diet are descending fruits (53.70\%), seeds (25.92\%), leaves $(22.22 \%)$, tubers (16.66\%), the flowers $(3.70 \%)$ and other (3.7\%).Analyses on food uses indicates that 40 respondents use them as recipes involve fruits and 11 use them to prepare sauce. Three (3) species are commonly used for the preparation of pap, 8 species for the preparation of cuscus and 3 species for the preparation drink.

Conclusion and application of results: The exploitation of these species remains traditional, sometimes leading to overexploitation of the resource and therefore a loss of biodiversity. For sustainable management of these resources, domestication of preferred species could be considered.
\end{abstract}

Keywords: NTFP, Biodiversity, Domestication, Mayo-Rey.

\section{INTRODUCTION}

Agricultural production in tropical Africa in general and Cameroon in particular is based on the shifting cultivation system otherwise referred to as Swidden short term (3-6 years) and a long period of rest (fallow) (Stéphanie, 1999). During the last decade, the use of natural resources in North region of Cameroon has become increasingly intensive with population growth and climate change (ICRAF,
1994). This has led a growing demand for food while land productivity declined (World Bank, 1984; 2002). The environment is negatively affected (Tchotsoua et al., 1998; Tchotsoua and Mapongmetsem, 2009). Faced with this problem, people make use of NonTimber Forest Products (NTFPs) like Dioscorea bulbifera, Tacca leontopetaloides, Oryza barthii, Detarium microcarpum, Ziziphus mauritiana, to fill 
the deficit in agricultural products and diversify their income (Larwanou et al., 2012). NTFP allow them to vary their diet and improve their standard of living (Hadji Sene, 1994; Tieguhong et al., 2008; Noubissie et al., 2008; Tieguhong and Zwolinski, 2009; Ingram et al., 2010, Mapongmetsem et al., 2010; Tiegohong et al., 2012). In order to protect certain species of socio-economic interest, it would be necessary to introduce farmers' backgrounds of new production systems to increase agricultural production and protect natural ecosystems. Indeed, the rational management of the environment is increasingly advocated to mitigate the current and future challenges. Agroforestry appears as one of the alternatives that can overcome these problems. One of its functions is the diversification of food production and income (Godoy and Bawa 1993; Ambrose-Oji, 2003; Tieguhong and Zwolinski, 2009; Ingram et al., 2010; Mapongmetsem et al.,2010; Tiegohong et al., 2012). Trees are the main component of agroforestry system. To further attract the interest from farmers, the introduction of trees of socioeconomic interest is an asset. Plants of interest are used for multiple purposes: food, medicine, energy, fertilizer and indispensable materials to manufacture populations commonly used tools (Christoph, 2002; Lamien and Traoré, 2002; FAO, 2003; Kouyaté et al., 2006; Bikouel

\section{MATERIAL AND METHODS}

This study was conducted between March and August 2009 in the Mayo-Rey localities: Tcholliré, Rey-Bouba, Mayo-Glaké, Madingring and Touboro. Mayo-Rey Division is in the Northern Region of Cameroon. The study area is located between latitudes $08^{\circ} 24^{\prime}$ and $08^{\circ} 36^{\prime}$ North and between longitudes $14^{\circ} 10^{\prime}$ and $14^{\circ} 24^{\prime}$ East of the Grenwich Meridian at an average altitude of $400 \mathrm{~m}$ above sea level. Benue Division, to the North East, bound it to the North in the South by the Adamawa Region and East by the Central African Republic (Fig.1). The climate is tropical with an average rainfall of $1000 \mathrm{~mm}$ to $1250 \mathrm{~mm} /$ year. The soil is sandy throughout the resort but in the plain of Mayo-Rey, alluvial soils are rich (Anonymous, 2007). The choice of locations is focused on three criteria: the presence of large market, ethnicity and extent of the and Essomba, 2006; Tchatat and Ndoye, 2006; Fasoyiro and Degoke, 2007; Bassene, 2008; Lacombe and Aronson, 2008; FAO et al, 2012). People usually have more than subsistence income from the forest (Sene, 2001; Vedeld et al., 2007; Paumgarten, 2007; Tieguhong et al., 2009). Moreover, the traditional abusive and uncontrolled exploitation of these resources affects their regeneration possibilities and can lead to their exhaustion (Kouyaté et al., 2006). In northern Cameroon, despite the unlimited demand for products justified by the increase in population (Tchingsabe, 2009; Mapongmetsem et al., 2010). Little information is available on domestic, nutritional intake, contribution to the welfare and socioeconomic potential of NTFPs (Mapongmetsem et al., 2008). This study was undertaken with a view to contribute to the knowledge gap in the role plants play on environmental sustainability and the contribution of NTFPs as food and drinks as well as alleviating rural poverty. The inventory of non-timber forest products in Mayo-Rey will develop appropriate strategies for their recovery and release their exploitation from informal. This work aims to characterize NTFP in the region for subsequent domestication. The following specific objectives have been assigned to this work: (1) identify the domestic and commercial use; (2) develop the type of NTFP in the region; (3) identify and analyse the major NTFPs of Mayo-Rey.

exploitation of NTFPs. The data collection method was based on structured interviews conducted in households and markets through previously developed questionnaires. Herbarium developed from samples collected was used to determine the scientific names of species. The survey was based on a sample of 50 people per village, 200 people interviewed in the Division. This sampling covered approximately $40.5 \%$ of the population over 18 years of the places visited. The classification method was based on the preference of each party. $\mathrm{He}$ attributed the number of points to species he preferred the most. Once the order of preference was indicated, a species list was submitted to respondents for checking compliance of their choice. Descriptive statistics were used to analyze the collected information. 


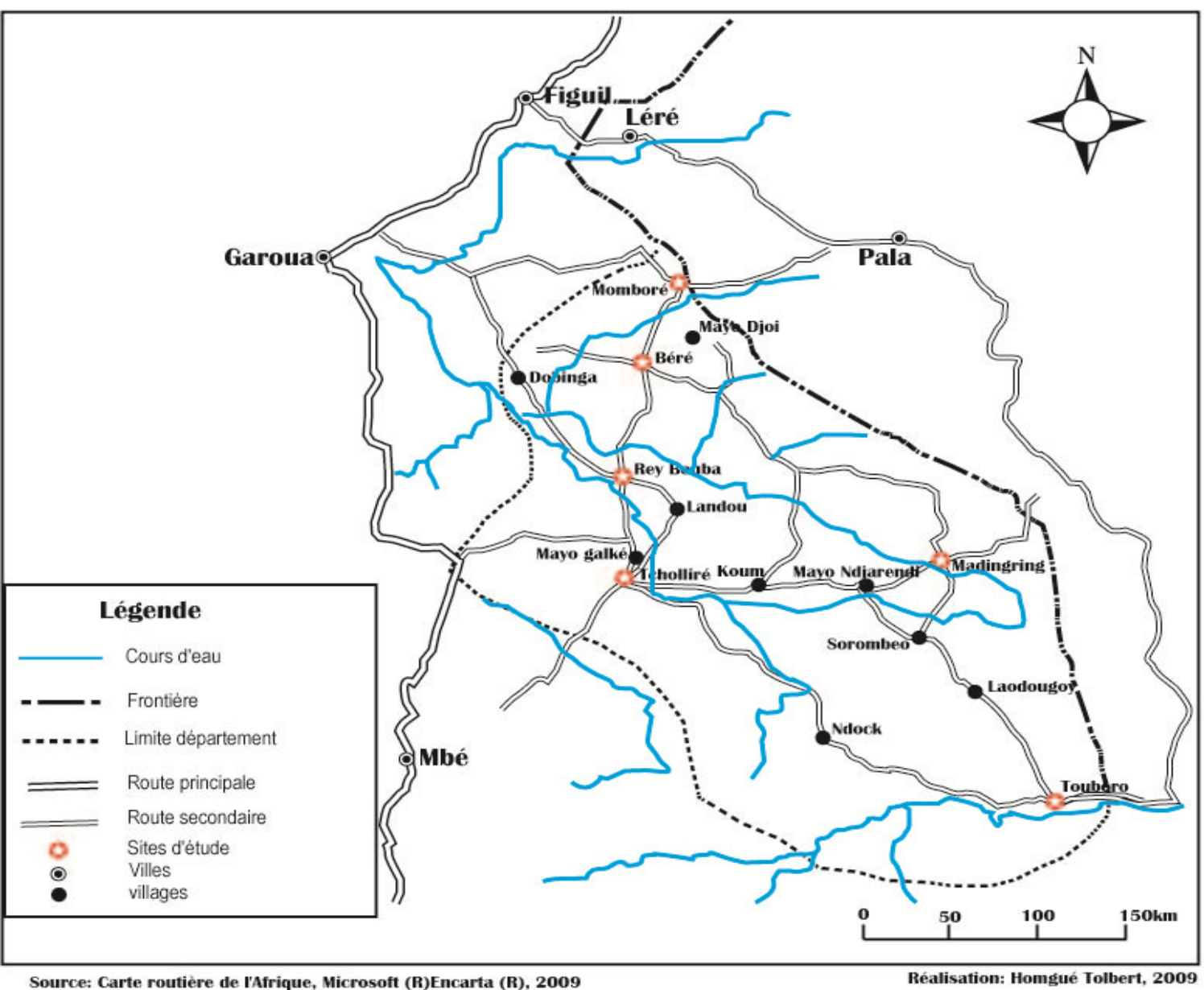

Figure 1: Locations of study area in Mayo-Rey Division.

\section{RESULTS}

Like most rural populations in developing countries, the people of Mayo-Rey feed, treat and provide income through the many forest products. Food species Ethnobotanical surveys reveal the existence of many food species. Ninety-five $(95 \%)$ of the people interviewed confirms these results. A total of 54 species that are consumed by the population was listed (Table 1). These species are distributed in 40 genera and 26 families. They are involved in several food recipes. Plant parts used in the diet are descending fruits (53.70\%), seeds (25.92\%), leaves (22.22\%), tubers (

$16.66 \%$ ), the flowers $(3.70 \%)$ and others $(3.7 \%)$. Analyses of food uses indicate that 40 respondents use them as recipes involve fruits and 11 use them to prepare sauce. Threes (3) species are commonly used for the preparation of the pap, 8 species for the preparation of cuscus and 3 species for the preparation drink.

The most popular food species: people for food (Table 2) use several species. The major species are appreciated by farmers for their socio-economic values are:

Vitellaria paradoxa, which is a popular fuel by local people, its ripe fruits, is consumed during fieldwork. Shea butter extracted from its almonds is a very important source of fat for cooking. Traditional extraction of shea butter is a women's activity (especially older women).

Dioscorea bulbifera is much consumed by the people of the locality of Madinring. The tubers are prepared with sheets Piliostigma thonningui to remove the bitter taste before consumption. The tubers are eaten much during the lean period. Women are more involved in the exploitation of this species.

Adansonia digitata is most popular for its leaves in the town of Mayo-Rey. These fall in the preparation of the traditional sauce that accompanies the cuscus corn, sorghum, rice, millet. These leaves are eaten in the cool and dry forms. In the dry form, the leaves are dried and powdered before use and conservation. The white fruit 
pulp can be sucked but diluted in water, it gives a sweet drink. This pulp is used by women for the preparation of the slurry. The leaves of desert date are consumed fresh and dry by the local people of Mayo-Rey as a sauce and as a traditional salad. The boiled seeds of this species are eaten as amuse gueule.

Borassus aethiopum: The fruits are consumed in mature and immature. The endosperm jelly of the fruit is also used to proclaim the hunger and thirst of the shepherds. The pulp of ripe fruit is eaten raw and during the lean period. The hypocotyl of seedlings or "bassi" in the local language is well known to all the people of Mayo-Rey for its food value and aphrodisiac. The leaves of Senna tora are consumed both fresh and dried forms. Fresh or dried leaves seasoned with peanut paste accompany cuscus. The manufacturing process of the flour Tacca leontopetaloides pass through several stages: buffing, pressing, filtering and recovering the supernatant until the disappearance of the bitter taste. White flour obtained at the end of the process is mixed with peanut paste for the preparation of traditional cakes or "Amankou" in local language. This flour is also used by women for preparing porridge and donuts.

The fruits of Ziziphus mauritiana are consumed fresh or dry as amuse gueule. The pulp of the seeds, powdered by women is mixed with peanut paste and kept waiting for the lean season. This dish is consumed during the fieldwork and the return of fields.

Tamarindus indica is a species highly prized by local people. The dissolution of fruit in water gives a sour drink. Women use for the preparation of the slurry.

Food values economic potentiality: Interviewed operators report that NTFPs harvesting are a source of income throughout yhe year as cash crops are mostly seasonal...and require a significant cost for labor of interview. Women and children are involved in the marketing of these products. NTFPs are sold in local markets. Traders are unanimous in that the means are insufficient for the purchase of inputs to increase agricultural productivity, which drives men to look more and more important to the economic value NTFPs. The leaves of Adansonia digitata are harvested in the natural stand, feet found in plantations, fields and Sares. These dried or processed powdered leaves are the subject of marketing channels villages to urban centres (Tcholliré, Toubouro, Madinring, Garoua, Yaoundé), and even cross the borders of Cameroon. The fruits are harvested from November. Fruit Vitellaria paradoxa and Detarium microcarpum have significant monetary value for children and women. They are sold in local markets. Shea butter extracts almonds Vitellaria paradoxa also a good monetary value on the market. The seeds are stored during the harvest season and the butter extraction extends throughout the dry season. This activity generates annual revenues ranging between 2,000 and 250,000 FCFA for small producers and 50,000 FCFA 300,000 to FCFA for large producers. The majority of the women interviewed agreed on the fact that the marketing of shea butter provides them with the resources to pay school fees for their children.

The pulp Hibiscus sabdarifa harvested in plantations is dried and sold in local markets and in the subregion. The pulp in the manufacture of a natural sweet drink ("hoyoro" in local language) that is highly prized by consumers. The annual revenues range from FCFA 60,000 to FCFA 200,000 per producer.

Parkia biglobosa fruit are eaten raw in the far north of Cameroon. Fermented seeds can also be packaged into small balls or "Dadawa" in local language. They are sold in local markets in the region and are used as a spice. The "Dadawa" has been a very active marketing system in general and in local markets in particular region. Socioeconomic surveys the fall and comments from industry stakeholders confirm that Tamarindus indica, Ximenia americana, Ziziphus mauritiana fruit are frequently encountered in the local markets of the Mayo-Rey. The annual revenue from their sales varies from 15,000 to 140,000 FCFA. The dried leaves of the herb Senna tora are frequently sold on local markets. Yearly income from their sale range from FCFA 13,000 to FCFA 32,000 . The products from the tubers of Tacca leontopetaloides and Dioscorea bulbifera are sold in local markets. The annual revenue from the sale range from FCFA 30,000 to FCFA 150,000 per farmer. Dejong et al. (2000) believe that the economic value of NTFPs can promote the conservation of biodiversity, contributed to the maintenance of resources and socio-economic development on a sustainable basis.

Constraint the operation of food species in the Mayo-

Rey: The majority of food plants are operated in a free manner. However, a minority part of an appropriation and operated by the only landowner. These are Parkia biglobosa, Vitellaria paradoxa, Tamarindus indica, Borassus aethiopum. These species are deliberately protected by the operators in their concessions or "Sare" and their fields. The stems of some food plants are declining in the localities of Mayo-Rey. The most cited species by operators are Parkia biglobosa, Vitellaria paradoxa, Tamarindus indica, Borassus aethiopum, Tacca leontopetaloides, Dioscorea bulbifera, Burnatia sp. and Detarium microcarpum. The causes of this decline are the abuse of NTFPs and timber, lack of regeneration 
and insufficient rains. In addition to the reduction of species, the means of transport is a limiting factor valuation of NTFPs towns of Mayo-Rey. The localities of Mayo-Rey are landlocked; transport vehicles are only available on market day. Operators face many problems

\section{DISCUSSION}

In communities of Mayo-Rey, NTFPs play an important role in socio-economic life of local people. They offer many products and services that are used by the population (FAO, 1998; 1999b; 2001a; 2002 Mbala and Walter, 2006). Their importance is vital in areas where they are a source of food and feed (Kouyaté et al., 2006). At the end of this study, several food species have been recorded. They are a source and an important reservoir of NTFPs in Mayo-Rey. The plants that bear edible NTFPs are subject to abuse by the operators. They offer leaves, fruits, tubers, roots and hypocotyl that are regularly harvested and consumed or sold on local markets. Knowledge of edible species and exploitation of NTFPs is to sell certain products to regional markets of Cameroon because of their perishable nature and harassment by agents of the Ministry of Forestry and Wildlife. Selfishness retailers wholesalers often hinder the exploitation of NTFPs in Mayo-Rey localities.

important for operators whose economy is based on the harvesting and marketing of NTFPs (Niéyidouba and San Torre, 2002; Sene, 2001; Mapongmesem et al., 2010). The majority of wild fruits, tubers and leafy vegetables enter the feed end of the dry season and during the rainy season. This interval corresponds to the lean period in rural areas. Most of the leaf development stage begins in April-May, just before the first rains. We can say that the periods of availability of edible NTFPs by local people is a relief that match the lean periods in households (Aïchatou, 2009). NTFPs are considered the last resort for local people.

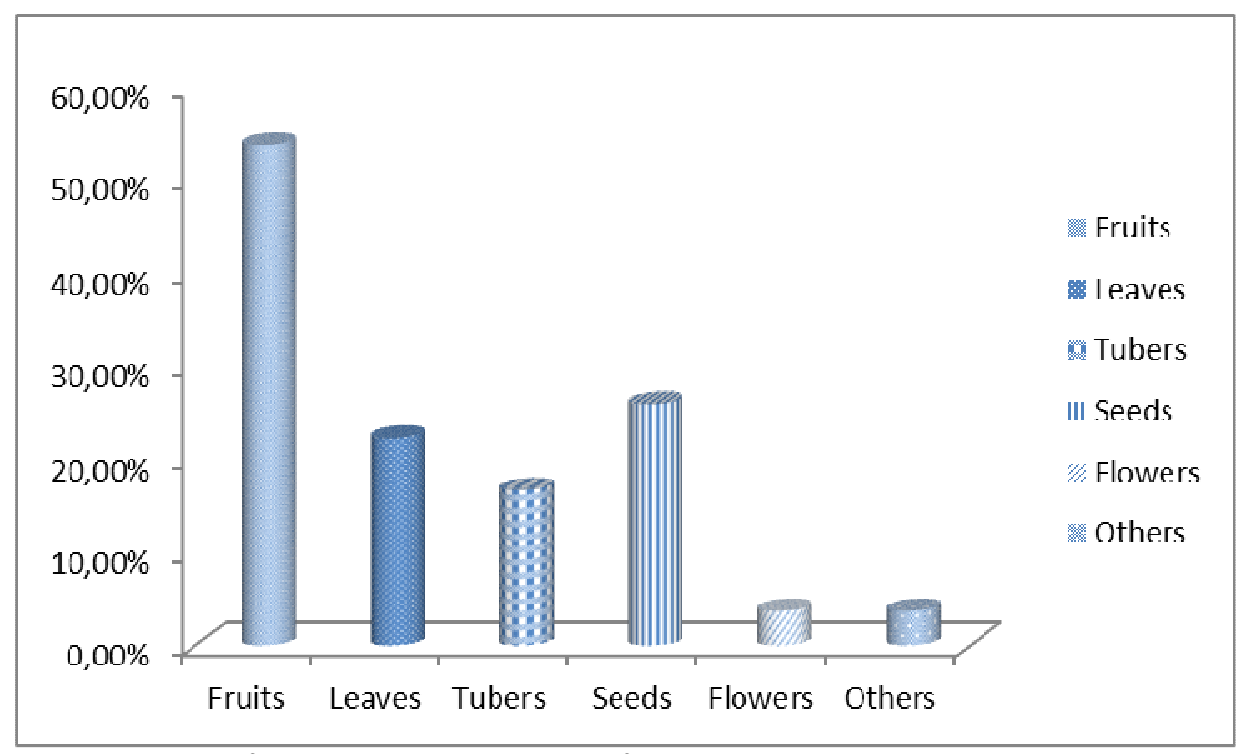

Figure 2: parts of the most used in the diet of local populations plants

Ethnobotanical surveys reveal the existence of many food species. Ninty five (95\%) of the people interviewed confirms these results 
Table 1: Parts of plants used by species and the local people of Mayo-Rey

\begin{tabular}{|c|c|c|c|c|}
\hline Species & Used Parts & Periods of Pickings & Way of Consuming & Products Purpose \\
\hline Adansonia digitata & $\mathrm{Fe}, \mathrm{Fr}$ & seasonal & Pap, Sau, Dri & Auto, sale \\
\hline Annona senegalensis & $\mathrm{Fr}$ & seasonal & Con & Auto, sale \\
\hline Balanites aegyptiaca & $\mathrm{Fe}, \mathrm{Fr}, \mathrm{Se}$ & seasonal & Sau, Pap, Con & Auto, sale \\
\hline Borassus aethiopicum & $\mathrm{Fr}, \mathrm{Hy}$ & all year & Con, Pap & Auto, sale \\
\hline Bridellia ferruginea & $\mathrm{Fr}$ & seasonal & Con & Auto \\
\hline Chromolaena spp. & $\mathrm{Fe}$ & seasonal & Sau & Auto, sale \\
\hline Detarium microcarpum & $\mathrm{Fr}$ & seasonal & Con & Auto, sale \\
\hline Diospyros mespiliformis & $\mathrm{Fr}$ & seasonal & Con & Auto \\
\hline Ficus spp. & $\mathrm{Fr}$ & seasonal & Con & Auto \\
\hline Ficus sycomorus & $\mathrm{Fr}$ & seasonal & Con & Auto \\
\hline Ficus valis choudae & $\mathrm{Fr}$ & seasonal & Con & Auto \\
\hline Grewia bicolor. & $\mathrm{Fr}, \mathrm{Te}$ & seasonal & Con, Sau & Auto, sale \\
\hline Hyphaene thebaeca & $\mathrm{Fr}$ & seasonal & Con & Auto, sale \\
\hline Lannea schimperi & $\mathrm{Fr}$ & seasonal & Con & Auto \\
\hline Nauclea latifolia & $\mathrm{Fr}$ & seasonal & Con & Auto \\
\hline Parinari curatillifolia & $\mathrm{Fr}$ & seasonal & Con & Auto \\
\hline Parkia biglobosa & $\mathrm{Fr}, \mathrm{Se}$ & seasonal & Con, Sau & Auto, sale \\
\hline Sclerocarya birrea & $\mathrm{Fr}, \mathrm{Se}$ & seasonal & Con & Auto, sale \\
\hline Syzygium macrocarpum & $\mathrm{Fr}$ & seasonal & Con & Auto \\
\hline Tamarindus indica & $\mathrm{Fr}, \mathrm{Fe}$ & seasonal & Con, Dri, Sau & Auto, sale \\
\hline Vitellaria paradoxa & $\mathrm{Fr}, \mathrm{Se}$ & seasonal & Con, Sau & Auto, sale \\
\hline Vitex doniana & $\mathrm{Fr}$ & seasonal & Con, Dri & Auto, sale \\
\hline Vitex madienis & $\mathrm{Fr}$ & seasonal & Con, Dri & Auto, sale \\
\hline Ximenia americana & $\mathrm{Fr}$ & seasonal & Con, Dri & Auto, sale \\
\hline Ziziphus mauritiana & $\mathrm{Fr}$ & seasonal & Con & Auto, sale \\
\hline Bixa orellana & Se & seasonal & Sau & Auto, sale \\
\hline Bombax costatum & $\mathrm{FI}$ & seasonal & Sau & Auto, sale \\
\hline Piliostigma thonningii & $\mathrm{Fr}$ & seasonal & Sau & Auto, sale \\
\hline Sesanum indicum & $\mathrm{Fe}$ & seasonal & Sau & Auto, sale \\
\hline Hibiscus sabdariffa & $\mathrm{Fe}, \mathrm{Fr}$ & seasonal & Sau, Dri & Auto, sale \\
\hline Ricinus communis & $\mathrm{Se}$ & seasonal & Sau & Auto \\
\hline Moringa oleifera & $\mathrm{Se}, \mathrm{Fr}$ & seasonal & Sau, con & Auto, sale \\
\hline Discorea bulbifera & $\operatorname{Tr}$ & all year & Pap & Auto, sale \\
\hline Discorea spp. & $\operatorname{Tr}$ & all year & Pap & Auto, sale \\
\hline Tacca leontopetaloides & $\mathrm{Tr}$ & all year & Boi, Fu & Auto, sale \\
\hline Nephtytis sp. & $\operatorname{Tr}$ & seasonal & Con & Auto \\
\hline Lannea acida & $\mathrm{Fr}, \mathrm{Tr}$ & seasonal & Con, & Auto \\
\hline Senna tora & $\mathrm{Fe}$ & seasonal & Sau & Auto, sale \\
\hline Senna occidentalis & Se & seasonal & Dri & Auto \\
\hline Grewia spp. & $\mathrm{Fr}$ & seasonal & Con & Auto \\
\hline Ficus polita & $\mathrm{Fr}$ & seasonal & Con & Auto \\
\hline Cleome coeruleorosea & $\mathrm{Fe}$ & seasonal & Sau & Auto, sale \\
\hline Cochospermu planchonii & $\operatorname{Tr}$ & seasonal & Con & Auto \\
\hline Citrullus lanatus & $\mathrm{Fe}$, & seasonal & Sau & Auto, sale \\
\hline Burnatia sp. & $\operatorname{Tr}$ & seasonal & Dri & Auto \\
\hline Bridelia ferruginea & $\mathrm{Fr}$ & seasonal & Con & Auto \\
\hline Amaranthus sp. & $\mathrm{Fe}$ & seasonal & Sau & Auto \\
\hline Haemastotaphis barteri & $\mathrm{Fr}$ & seasonal & Con, Dri & Auto \\
\hline Daweji (Fufulde) & $\operatorname{Tr}$ & all year & Con & Auto \\
\hline Leptadenia hastata & $\mathrm{Fe}$ & all year & Sau, Con & Auto \\
\hline Sinseni (Fufulde) & $\mathrm{Te}$ & all year & Dri & Auto \\
\hline Dactyloctenium aegyptium & Se & seasonal & $\mathrm{Cu}$ & Auto \\
\hline Oryza barthii & $\mathrm{Se}$ & seasonal & $\mathrm{Cu}$ & Auto \\
\hline Setaria pumila & $\mathrm{Se}$ & seasonal & $\mathrm{Cu}$ & Auto \\
\hline
\end{tabular}

Auto : Autoconsumption ; sale : marketable; Con : direct consumption of the fruits or grains ; Sau : Preparation of the sauce ; Pap : Preparation of the pap ; Dri : Preparation of drinks ; Cu : Preparation of cuscus ; Fr : Fruit ; Fe : leaf ; Tr : Tuber; FI : Flower; Se : seed ; Hy : Hypocotyle. 
Tchingsabe et al., J. Appl. Biosci. 2016 Valorization of non-timber forest products in Mayo-Rey (North Cameroon)

Table 2: Frequency of food plants of Mayo-Rey (\%)

\begin{tabular}{|c|c|c|c|c|c|}
\hline Species & Laka & Lamé & Peuhl & Toupouri & Average \\
\hline Adansonia digitata & 48 & 64 & 76 & 60 & 62,0 \\
\hline Annona senegalensis & 56 & 68 & 52 & 74 & 62,5 \\
\hline Balanites aegyptiaca & 6 & 48 & 14 & 6 & 18,5 \\
\hline Borassus aethiopum & 0 & 36 & 24 & 0 & 15,0 \\
\hline Bridellia ferruginea & 12 & 4 & 24 & 10 & 12,0 \\
\hline Chromolaena spp. & 0 & 72 & 0 & 0 & 18,0 \\
\hline Detarium microcarpum & 42 & 64 & 62 & 60 & 57,0 \\
\hline Diospyros mespiliformis & 30 & 72 & 68 & 60 & 57,5 \\
\hline Ficus spp. & 12 & 18 & 16 & 20 & 16,5 \\
\hline Ficus sycomorus & 10 & 62 & 22 & 26 & 30,0 \\
\hline Ficus valis choudae & 24 & 56 & 68 & 60 & 52,0 \\
\hline Grewia bicolor. & 70 & 46 & 56 & 48 & 55,0 \\
\hline Hyphaene thebaeca & 12 & 44 & 42 & 14 & 25,5 \\
\hline Lannea schimperi & 26 & 28 & 12 & 8 & 18,5 \\
\hline Nauclea latifolia & 32 & 26 & 20 & 28 & 26,5 \\
\hline Parinari curatillifolia & 30 & 8 & 10 & 0 & 12,0 \\
\hline Parkia biglobosa & 84 & 40 & 0 & 0 & 17,5 \\
\hline Sclerocarya birrea & 0 & 76 & 64 & 52 & 48,0 \\
\hline Syzygium macrocarpum & 30 & 8 & 8 & 16 & 15,5 \\
\hline Tamarindus indica & 36 & 72 & 92 & 64 & 66,0 \\
\hline Vitellaria paradoxa & 92 & 74 & 80 & 68 & 78,5 \\
\hline Vitex doniana & 52 & 76 & 60 & 72 & 65,0 \\
\hline Vitex madienis & 16 & 50 & 18 & 20 & 26,0 \\
\hline Ximenia americana & 50 & 62 & 64 & 56 & 58,0 \\
\hline Ziziphus mauritiana & 24 & 60 & 48 & 32 & 41,0 \\
\hline Bixa orellana & 22 & 30 & 64 & 28 & 36,0 \\
\hline Bombax costatum & 20 & 40 & 28 & 30 & 29,5 \\
\hline Piliostigma thonningii & 40 & 82 & 84 & 88 & 64,5 \\
\hline Sesanum indicum & 12 & 48 & 86 & 52 & 49,5 \\
\hline Hibiscus sabdariffa & 52 & 76 & 60 & 72 & 65,0 \\
\hline Ricinus communis & 0 & 0 & 0 & 40 & 10,0 \\
\hline Moringa oleifera & 10 & 0 & 0 & 0 & 2,5 \\
\hline Discorea bulbifera & 96 & 64 & 40 & 10 & 52,5 \\
\hline Discorea spp. & 82 & 83 & 52 & 71 & 72,0 \\
\hline Tacca leontopetaloides & 10 & 65 & 31 & 20 & 31,5 \\
\hline Nephtytis sp. & 0 & 20 & 15 & 25 & 15,0 \\
\hline Lannea acida & 5 & 16 & 18 & 20 & 13,6 \\
\hline Senna tora & 35 & 86 & 89 & 70 & 70,0 \\
\hline Senna occidentalis & 40 & 30 & 56 & 39 & 41,2 \\
\hline Grewia spp. & 80 & 15 & 27 & 25 & 36,7 \\
\hline Ficus polita & 15 & 10 & 9 & 7 & 10,2 \\
\hline Cleome coeruleorosea & 0 & 70 & 60 & 0 & 32,5 \\
\hline Cochospermu planchonii & 30 & 25 & 10 & 0 & 16,2 \\
\hline Citrullus lanatus & 0 & 17 & 14 & 0 & 7,7 \\
\hline Burnatia sp. & 0 & 0 & 50 & 0 & 12,5 \\
\hline Bridelia ferruginea & 12 & 30 & 28 & 26 & 24,0 \\
\hline Amaranthus sp. & 10 & 60 & 25 & 0 & 23,7 \\
\hline Haemastotaphis barteri & 0 & 15 & 55 & 12 & 20,5 \\
\hline Daweji (Fufulde) & 25 & 46 & 57 & 62 & 47,5 \\
\hline Leptadenia hastata & 0 & 12 & 0 & 0 & 3,0 \\
\hline Sinseni (Fufulde) & 0 & 0 & 20 & 0 & 5,0 \\
\hline Dactyloctenium aegyptium & 13 & 25 & 40 & 0 & 19,5 \\
\hline Oryza barthii & 15 & 36 & 25 & 26 & 25,5 \\
\hline Setaria pumila & 0 & 9 & 16 & 7 & 8,0 \\
\hline Average & 26,44 & 41,55 & 38,13 & 29,40 & 33,32 \\
\hline
\end{tabular}




\section{CONCLUSION}

The study of Non Timber Forest Product identified 107 plant species 54 of which has food values value (vegetables, fruits, tubers, traditional drinks) were counted. The picking fruits, leaves and harvest the tubers of these species occupy an important place in the lives of local people, both during the sufficiency period and that of food shortage. NTFPs are used for auto consumption. They are sold on the market by women and children; these provide them substantial incomes that allow them to meet their basic needs. Efforts should be provided on the

\section{REFERENCES}

Ambrose-Oji B., 2003. The contribution of NTFPs to the livelihoods of the 'forest poor': evidence from the tropical forest zone of south-west Cameroon. Int Forest Rev. 5(2):106-117.

Anonyme, 2007. Tcholliré, Cameroun pag. Maps, weather and Airport for Tcholliré. http: // www. Fallingrain. Com / world / CM / Tcholliré. Htlm. $2 p$.

Bassene E., 2008. Impact des produits médicaux à usage vétérinaire alternatifs et traditionnels en Afrique. Conférence de I'OIE sur les médicaments vétérinaires en Afrique, Dakar, 2527 mars, $7 \mathrm{p}$.

Bikoue1 M. A. C et Essomba H., 2006. Gestion des ressources naturelles fournissant les produits forestiers non-ligneux alimentaires en Afrique Centrale. FAO, Département des Forêts, $103 p$.

Christoph D., 2002. Le rôle de la forêt et des arbres dans la lutte contre la pauvreté. $19 p$.

De Jong W., Campbell B. M. and Schroder, J-M., 2000. «Sustaining incomes from non timber forest products: introduction and synthesis ». International Tree Crops Journal, 10 (4): 267275.

ICRAF/CILSS., 1994. Agroforesterie au sahel. Bibliographie Annotée. Volume II.

FAO, WFP and IFAD, 2012. The State of Food Insecurity in the World. Economic growth is necessary but not sufficient to accelerate reduction of hunger and malnutrition. FAO, Rome. http://www.fao.org/docrep/016/3027e/3027e.pdf (Accessed 31st October 2013).

FAO, 2003. La collecte et l'analyse des données statistiques sur les produits forestiers nonligneux, une étude pilote à Madagascar. Programme produits forestiers non-ligneux, Département des forêts, $113 p$. domestication of major species at high socio-economic value to improve their production in agroforestry systems. Models of sustainable exploitation and the valorization of multi-purpose tree species should be encouraged to reduce the risk of food insecurity and the degradation of biodiversity in the Mayo-Rey. It would encourage operators to bring their plantations major food species. Research on the nutritional value of consumed parts should be conducted in the future.

FAO, 2001a. Evaluation des ressources en produits forestiers non-ligneux. $118 \mathrm{p}$.

FA O, 1998. Essaie de démonstration des réalités sur l'exploitation des PFNL au Cameroun. 6p.

FAO, 1999b. Données statistiques des produits forestiers non-ligneux du Cameroun, FAO, Rome, $36 \mathrm{p}$.

Fasoyiro and Adegoke., 2007. Phytochemical characterization and the antimicrobial property of Aframomum daniellii extract. African journal of Agricultural research. 3 (2): 076-079.

Godoy R. A. and Bawa K.S., 1993. The economic value and sustainable harvest of plants and animals from the tropical forest: assumptions, hypotheses and methods. Econ Bot. 47(3):215219.

Kouyaté A, Van D. P et Diawara H., 2006. Évaluation de la production en fruits de Detarium microcarpum Guill. \& Perr. au Mali. Fruits, vol 61, n4, pp. 267-272.

Lacombe $\mathrm{M}$ et Aronson J., 2008. La restauration du capital naturel en zones arides et semi-arides. Allier santé des écosystèmes et bien-être des populations. Les dossiers thématiques du CSFD. Numéro 7. 36 p.

Lamien $\mathrm{N}$ et Traoré S., 2002. Commercialisation des produits non-ligneux des arbres de la zone semiaride du Burkina Faso : cas des feuilles sèches du baobab (Adansonia digitata L.). 2è atelier régional sur les aspects socio-économiques de l'agroforesterie au sahel. Bamako du 04 au 06 mars. $9 \mathrm{p}$.

Larwanou M, Dan Guimbo I, Oscar EM and Issaka Al., 2012. Farmer managed tree natural regeneration and diversity in a sahelian environment: case study of Maradi region, Niger. Continental J. Agricultural Science, 6(3): 38-49.

Lescuyer G., 2010. Importance économique des Produits Forestiers Non-Ligneux dans quelques villages 
du Sud-Cameroun [Economic importance of NTFPs in some villages of South Cameroon]. Bois et Forêts des Tropiques. 304(2):15-24.

Mapongmetsem P. M., Hamawa Y., Djeumene P., Maissele, Kossebe C. F., Duryant J. B., Bebbe F., Bouba D., Wouldata S., Zigro L. et Barbi M., 2008. Valorisation des plantes alimentaires sauvages des savanes soudano- guinéennes. Conf. Iterns. Développement de l'agroalimentaire et création des richesses. 0911juillet 2008. ENSAI. Ngaoundéré, Cameroun. $14 \mathrm{p}$.

Mapongmetsem P. M., Tchingsabé O., Kemeuze V. et Damba A., 2010. Utilisation et commercialisation des produits forestiers non-ligneux par les communautés locales dans les savanes soudaniennes. XIXe congres de l'AETFAT : 2630 avril 2010, Antarivo, Madagascar.

Niéyidouba Lamien et San Traore., 2002. Commercialisation des produits non des arbres de la zone semi- aride du Burkina Faso : cas des feuilles sèches de baobab (Adansonia digitata L.). $9 p$.

Noubissie E., Chupezi T. J., and Ndoye O., 2008. Analyse des aspects socio-économiques des produits forestiers non-ligneux (PFNL) en Afrique Centrale. Synthèse des Rapports d'études réalisées dans le cadre du Projet Gcp/Raf/398/Ger. FAO. Yaoundé, Cameroun: FAO GCP/RAF/398/GER. Renforcement de la sécurité alimentaire en Afrique Centrale à travers la gestion et l'utilisation durable des produits forestiers non ligneux.

Paumgarten F., 2007. The Significance Of The SafetyNet Role Of NTFPs In Rural Livelihoods, South Africa, Environmental Sciences, Rhodes University, Grahamstown, South Africa.

Sène A., 2001. Exploitation et valorisation des PFNL dans la région de kola. Caractérisation des acteurs de base. Conservation : ISSRA, BAME et UICN. Dakar, Sénégal. pp.5-15

Stéphanie C., 1999. Influence de l'agriculture itinérante sur brulis des Ntumu et des pratiques agricoles associées sur la dynamique forestière du Sud Cameroun, Thèse Doctorat. 439p.

Tchatat M. et Ndoye O., 2006. Etude des produits forestiers non ligneux d'Afrique Centrale : réalités et perspectives. Bois et Forêts des Tropiques, Nº 288 (2), pp. 27-39.
Tchingsabé O., 2007. Produits Forestiers Non Ligneux et qualité dans le Mayo- Rey (Nord- Cameroun). Mémoire de Maîtrise (Biologie et Physiologie Végétale), Faculté des Sciences, Université de Ngaoundéré, $62 \mathrm{P}$.

Tchingsabé O., 2009. Produits Forestiers Non Ligneux et propriétés antioxydantes des espèces Majeures dans la zone soudanienne (Mayo- Rey, NordCameroun). Mémoire de Master (Biologie des Organismes Végétaux), Faculté des Sciences, Université de Ngaoundéré, $80 \mathrm{P}$.

Tchotsoua M., Mohamadou G., Esoh E., et Ngana J. P., 1998. Dianoctic de l'état de l'environnement de Ngaoundéré et contribution pour une approche de gestion partagée. Annales de FALSH de I'Université de Ngaoundéré. III. 99-114.

Tchotsoua M., et Mapongmetsem P. M., 2009. Surpâturage et conquête forestière des savanes de l'Adamaoua Cameroun. Rev. Géogr. Cam. (Sociétés et environnement). 9p.

Tieguhong J. C., Ndoye O., and Ekati J. E., 2008. Community based NTFP production and trade for rural poverty alleviation and resource conservation: Case of Prunus africana on Mount Cameroon, Cameroon.

Tieguhong J. C., Ndoye O., Vantomme P., Zwolinski J., and Masuch J., 2009. Coping with crisis in Central Africa: enhanced role for non-wood forest products. Unasylva 233 (60):49-54.

Tieguhong J. C., and Zwolinski J., 2009. Supplies of bush meat for livelihoods in logging towns in the Congo Basin. Journal of Horticulture and Forestry 1 (5).

Tieguhong , J. C. , O. Ndoye, S. Grouwels, W. A. Mala, and J. L. Betti, 2012 . Rural enterprise development for poverty alleviation based on non- wood forest products in Central Africa . International Forestry Review. 14, $363-379$ (17).

Vedeld P., Angelsen A., Bojö J., Sjaastad E., and Kobugabe Berg G., 2007. Forest environmental incomes and the rural poor. Forest Policy and Economics 9 (7):869-879.

Walter S et Mbala S.M., 2006. Etat des lieux du secteur produits forestiers nonligneux en Afrique Centrale et analyse des priorités. Note d'information du 19 au 21 septembre. pp.10-15 